\title{
Effects of Oral Zinc Supplementation in Diabetic Children and Adolescents with Asymptomatic Cardiac Insult
}

\author{
REHAM M. ATALLA, M.Sc.*; OSAMA ABD RAB EL-RASOL, M.D.*; \\ WESAM S. MOHAMMED, M.D.** and SHYMAA M. EL-RIFAEY, M.D.* \\ The Departments of Pediatric* and Clinical Pathology**, Faculty of Medicine, Tanta University
}

\begin{abstract}
Background: Diabetes is a pro-inflammatory condition. Chronic inflammation plays an important role in the progression of diabetic complications. High glucose levels induce the release of pro-inflammatory cytokines, including TNF-a, IL- 13 , and IL- 6 in patients with both type 1 and type 2 diabetes leading to multiorgan failure. Cardiovascular disease (CVD) is recognized as the major cause of morbidity and mortality among diabetic patients. Oxidative stress is a key risk factor contributing to the development and progression of CVDs. Zinc protects the cell from oxidation damage by free radicals. Zinc also act as anti- inflammatory.
\end{abstract}

Aim of Study: It was to evaluate the recent echocardiographic modalities in detection of silent left ventricular dysfunction in children with type 1 diabetes mellitus, assess the potential role of oxidative stress inflammatory cytokines, apoptosis and fibrosis in diabetic cardiac insult and to investigate the possible protective role of zinc supplement on diabetic left ventricle (LV) in type 1 diabetic children and adolescents.

Patients and Methods: The study was carried out on fifty patients with type 1 diabetes mellitus who were diagnosed and followed-up in Endocrinology Unit and endocrinology outpatient clinic, Pediatric Department, Tanta University Hospital. Subdivided into: Twenty-five patients who received insulin treatment only and twenty-five patients who received insulin and oral zinc supplementation according to their Dietary Recommended Intakes (DRI) $(7.5-15 \mathrm{mg} / \mathrm{d}$ ) for 6 months. Also on twenty-five apparently healthy children with matched age and sex who served as a control group. All studied children were subjected to detailed history taking, complete physical examination, measurement of level of IL6 before and after zinc supplementation also Echocardiography (conventional, tissue Doppler and Speckling Tracking Technique) before and after zinc supplementation.

Results: There was statistical significance between the 2 diabetic groups and the controls according to level of interleukin 6 which was markedly elevated in the diabetic patients than the controls. There was statistically significance between

Correspondence to: Dr. Reham M. Atalla, The Department of Pediatric, Faculty of Medicine, Tanta University the 2 diabetic groups and the controls according to the parameters detected by Tissue Doppler as E/A ratio and MPI (myocardial performance index) which showed subclinical systolic and diastolic impairment in the diabetic patients than the controls. There was statistically significance between the 2 diabetic groups and the controls according to the parameters detected by speckle tracking as 2DS (2 dimensional strain) which show subclinical systolic impairment in the diabetic patients than the controls. There was no statistical significance between the 2 diabetic groups and the controls according to the parameters detected by Tissue Doppler as ejection fraction and mitral annulus systolic velocity. There was no statistically significant difference between the diabetic patients who received oral zinc supplementation for 6 months and the controls according to level of interleukin 6 . This shows the effect of zinc supplementation as anti-inflammatory. There was no statistically significant difference between the diabetic patients who received oral zinc supplementation for 6 months according to the parameter detected by Tissue Doppler and speckle tracking (E/A ratio, MPI, 2DS) which show marked improvement in the systolic and diastolic function of the diabetic patient after zinc supplementation.

Conclusion: There is evidence of increase level of serum interleukin 6 in patients with type $1 \mathrm{DM}$. Also evidence of subclinical systolic and diastolic dysfunction in asymptomatic diabetic patients assessed by two-dimensional speckle tracking echocardiography and Tissue Doppler. Oral Zinc supplementation has a significant beneficial effect in patients with type $1 \mathrm{DM}$ due to the anti-inflammatory and cardio-protective effect of the Zinc.

Key Words: Diabetes Milletus - Zinc - IL6-Cardio-protective.

\section{Introduction}

DIABETES is a proinflammatory condition and chronic inflammation plays an important role in the progression of diabetic complications. Hyperglycemia has been implicated as a major contributor in several diabetes complications. As high glucose levels induce the release of proinflammatory cytokines, including TNF-a, IL-1 3 , and IL-6, in patients with both type 1 and type 2 diabetes [1] . 
The chronic and systematic influence of hyperglycemia, hyperlipidemia, activation of inflammatory cytokines, and concomitant metabolic changes in DM brings damage to multiorgan systems. The consequence of multiorgan injuries is the initiation of various diabetic complications, including the eyes, kidneys, blood vessels, nerves, and heart. Cardiovascular disease (CVD) is recognized as the major cause of morbidity and mortality among diabetic patients [2]

Type 1 diabetes increases the risk of cardiovascular disease by more than 10 times, relative to general population. The spectrum of diabetic heart disease involves progresses from normal heart to preclinical left ventricular diastolic dysfunction followed by overt echo evidence of LV dysfunction and finally symptomatic heart failure [3]

Adequate monitoring of the control is very important to document that metabolic disturbance is no longer in action and to make the occurrence of diabetic complications a remote possibility [4]

So many studies were done for control of the disease and progression of complication. In our study we evaluated the role of zinc which is an essential micronutrient that is involved in the regulation of the innate and adaptive immune responses with its effect as antioxidant and antiinflammatory on the diabetic children. Also, evaluating the preventive effect of $\mathrm{Zn}$ supplementation on diabetes-induced injury to the diabetic heart [5].

\section{Aim of the work:}

It was to evaluate the recent echocardiographic modalities in detection of silent left ventricular dysfunction in children with type 1 diabetes mellitus, assess the potential role of oxidative stress inflammatory cytokines, apoptosis and fibrosis in diabetic cardiac insult and to investigate the possible protective role of zinc supplement on diabetic left ventricle (LV) in type 1 diabetic children and adolescents.

\section{Patients and Methods}

The case control study was conducted on 75 children between (5-18 years) who were classified into: 50 patients (Group I) with type 1 diabetes mellitus and 25 healthy controls (Group II).

Patients (Group I) included 50 patients suffering from type 1 diabetes mellitus who were diagnosed and followed-up in Endocrinology Unit and endocrinology outpatient clinic of Pediatric Department of Tanta University Hospitals from April 2017

May 2018. Subdivided into:

- Group Ia: Twenty-five patients who received insulin treatment only.

- Group Ib: Twenty-five patients who received insulin and oral zinc supplementation according to their Dietary Recommended Intakes (DRI) (7.5- 15mg/d) for 3 months with pre and post assessment by Echo and measurement of serum IL6.

Exclusion criteria: Children with congenital heart diseases, acquired cardiac diseases, other systemic diseases, metabolic or genetic diseases.

All the studied patients were subjected to the following: Full history taking, clinical examination, routine investigations (complete blood count, creactive protein, Blood glucose level, Glycosylated Haemoglobin), Plasma level of IL-6 were determined before and after treatment and Echocardiographic Examination which included M-mode measurements, Transthoracic 2DE Examination, Tissue Doppler Examination including (systolic and diastolic mitral and tricuspid annulus velocities and Myocardial Performance Index) and Speckle Tracking Technique including (left Ventricular Longitudinal Systolic Strain Analysis and AutoEF for LV systolic function).

Statistical presentation and analysis of the present study was conducted using the mean, standard deviation, student $t$-test, Chi-square, F-test (ANOVA), Pearson coefficient, Spearman coefficient, Paired $t$-test by IBM SPSS software package version 20 with $p<0.05$ means significance.

\section{Results}

This study was carried out upon 50 diabetic patients with type $1 \mathrm{DM}$ and 25 non diabetic control cases, both patients and control were cross matched for age and sex. Table (1) show that regarding demographic and anthropometric data of the Studied Patients. There was no statistically significant difference throughout the study between the studied groups as regard age, height, weight and body mass index.

Table (3) demonstrated that the mean level of IL6 was significantly higher in both diabetic groups than the controls before receiving oral zinc supplementation. Also demonstrated that patient who received oral zinc supplementation showed significant lowering in mean level of IL6 than those who didn't receive oral zinc supplementation. 
Table (1): Descriptive data of diabetic children and controls.

\begin{tabular}{|c|c|c|c|c|c|}
\hline & \multicolumn{3}{|c|}{ Groups } & \multicolumn{2}{|c|}{ ANOVA } \\
\hline & $\begin{array}{l}\text { Diabetic children who } \\
\text { received oral zinc } \\
(\mathrm{n}=25)\end{array}$ & $\begin{array}{l}\text { Diabetic children who } \\
\text { didn't receive oral zinc } \\
(\mathrm{n}=25)\end{array}$ & $\begin{array}{l}\text { Controls } \\
(\mathrm{n}=25)\end{array}$ & $\mathrm{F}$ & $p$-value \\
\hline $\begin{array}{l}\text { Age (years): } \\
\text { Range } \\
\text { Mean } \pm \mathrm{SD}\end{array}$ & $\begin{array}{l}5-13 \\
7.960 \pm 2.835\end{array}$ & $\begin{array}{l}5-14 \\
8.200 \pm 2.483\end{array}$ & $\begin{array}{l}5-13 \\
8.520 \pm 2.417\end{array}$ & 0.295 & 0.745 \\
\hline $\begin{array}{l}\text { Weight }(k g): \\
\text { Range } \\
\text { Mean } \pm \text { SD }\end{array}$ & $\begin{array}{l}17-52 \\
28.360 \pm 11.870\end{array}$ & $\begin{array}{l}16-55 \\
29.120 \pm 10.252\end{array}$ & $\begin{array}{l}16-50 \\
29.880 \pm 10.039\end{array}$ & 0.125 & 0.883 \\
\hline $\begin{array}{l}\text { Height }(\mathrm{cm}): \\
\text { Range } \\
\text { Mean } \pm \text { SD }\end{array}$ & $\begin{array}{l}105-156 \\
125.200 \pm 16.763\end{array}$ & $\begin{array}{l}107-155 \\
127.840 \pm 13.870\end{array}$ & $\begin{array}{l}106-155 \\
129.120 \pm 14.298\end{array}$ & 0.442 & 0.644 \\
\hline $\begin{array}{l}\text { Body mass index }(\%): \\
\text { Range } \\
\text { Mean } \pm \mathrm{SD}\end{array}$ & $\begin{array}{l}14-21 \\
16.920 \pm 2.040\end{array}$ & $\begin{array}{l}14-22 \\
17.120 \pm 2.333\end{array}$ & $\begin{array}{l}14-29 \\
17.880 \pm 3.180\end{array}$ & 0.976 & 0.382 \\
\hline
\end{tabular}

Table (2): Demonstrate that the mean FBS, 2HPP and HbA1c were significantly higher in both diabetic groups than the controls.

\begin{tabular}{|c|c|c|c|c|c|c|c|c|}
\hline & \multicolumn{3}{|c|}{ Groups } & \multicolumn{2}{|c|}{ ANOVA } & \multicolumn{3}{|c|}{ TUKEY'S Test } \\
\hline & $\begin{array}{l}\text { Diabetic children } \\
\text { who received } \\
\text { oral zinc }(n=25)\end{array}$ & $\begin{array}{l}\text { Diabetic children } \\
\text { who didn't receive } \\
\text { oral zinc }(\mathrm{n}=25)\end{array}$ & $\begin{array}{l}\text { Controls } \\
(\mathrm{n}=25)\end{array}$ & $\mathrm{F}$ & $p$-value & I\&II & I\&III & II\&III \\
\hline \multicolumn{9}{|c|}{$\begin{array}{l}\text { Fasting blood sugar } \\
(\mathrm{mg} / \mathrm{dl}) \text { : }\end{array}$} \\
\hline Range & $130-180$ & $135-160$ & $75-95$ & 549.593 & $<0.001 *$ & 0.371 & $<0.001 *$ & $<0.001 *$ \\
\hline Mean \pm SD & $140.000 \pm 5.951$ & $142.600 \pm 7.921$ & $86.200 \pm 6.338$ & & & & & \\
\hline \multicolumn{9}{|c|}{$\begin{array}{l}\text { 2hour post prandial } \\
(\mathrm{mg} / \mathrm{dl}) \text { : }\end{array}$} \\
\hline Range & $210-300$ & $215-255$ & $120-155$ & 402.465 & $<0.001 *$ & 0.712 & $<0.001 *$ & $<0.001 *$ \\
\hline Mean \pm SD & $238.400 \pm 18.012$ & $235.200 \pm 13.029$ & $137.000 \pm 11.180$ & & & & & \\
\hline \multicolumn{9}{|l|}{$H b A 1 c(\%):$} \\
\hline Range & $7-10$ & $7-9$ & $3-4$ & 352.433 & $<0.001 *$ & 0.974 & $<0.001 *$ & $<0.001 *$ \\
\hline Mean \pm SD & $8.200 \pm 0.866$ & $8.160 \pm 0.688$ & $3.960 \pm 0.200$ & & & & & \\
\hline
\end{tabular}

Table (3): Serum level of IL6 in patients and control basal and after 6 month.

\begin{tabular}{|c|c|c|c|c|c|c|c|c|}
\hline \multirow[b]{2}{*}{$\begin{array}{l}\text { Inerleukin } 6 \\
(\mathrm{pg} / \mathrm{ml})\end{array}$} & \multicolumn{3}{|c|}{ Groups } & \multicolumn{2}{|c|}{ ANOVA } & \multicolumn{3}{|c|}{ TUKEY'S Test } \\
\hline & $\begin{array}{l}\text { Diabetic children } \\
\text { who received } \\
\text { oral zinc }(n=25)\end{array}$ & $\begin{array}{l}\text { Diabetic children } \\
\text { who didn't receive } \\
\text { oral zinc }(n=25)\end{array}$ & $\begin{array}{l}\text { Controls } \\
(\mathrm{n}=25)\end{array}$ & $\mathrm{F}$ & $p$-value & I\&II & I\&III & II\&III \\
\hline $\begin{array}{l}\text { Basal (at the stc } \\
\text { the study): }\end{array}$ & & & & & & & & \\
\hline $\begin{array}{l}\text { Range } \\
\text { Mean } \pm \text { SD }\end{array}$ & $\begin{array}{l}15-70 \\
39.040 \pm 16.159\end{array}$ & $\begin{array}{l}15-60 \\
39.520 \pm 12.794\end{array}$ & $\begin{array}{l}5-15 \\
8.800 \pm 2.799\end{array}$ & 53.695 & $<0.001 *$ & 0.989 & $<0.001 *$ & $<0.001 *$ \\
\hline $\begin{array}{l}\text { After } 6 \text { months: } \\
\text { Range } \\
\quad \text { Mean } \pm \mathrm{SD}\end{array}$ & $\begin{array}{l}5-20 \\
12.000 \pm 3.719\end{array}$ & $\begin{array}{l}15-65 \\
40.360 \pm 14.402\end{array}$ & $\begin{array}{l}5-15 \\
8.800 \pm 2.799\end{array}$ & 98.798 & $<0.001 *$ & $<0.001 *$ & 0.403 & $<0.001 *$ \\
\hline $\begin{array}{l}\text { Differences: } \\
\quad \text { Mean } \pm \text { SD }\end{array}$ & $27.040 \pm 15.496$ & $-0.840 \pm 2.656$ & & & & & & \\
\hline $\begin{array}{l}\text { Paired test: } \\
\quad p \text {-value }\end{array}$ & $<0.001 *$ & 0.127 & & & & & & \\
\hline
\end{tabular}

Significant $p$-value $<0.001^{*}$. 
Table (7): Comparison between diabetic children and control as regard Myocardial Performance Index (MPI) measured by Tissue Doppler Imaging (T.D.I.).

\begin{tabular}{|c|c|c|c|c|c|c|c|c|}
\hline \multirow[b]{2}{*}{ MPI } & \multicolumn{3}{|c|}{ Groups } & \multicolumn{2}{|c|}{ ANOVA } & \multicolumn{3}{|c|}{ TUKEY'S Test } \\
\hline & $\begin{array}{l}\text { Diabetic patients that } \\
\text { received insulin oral } \\
\text { zinc }(\mathrm{n}=25)\end{array}$ & $\begin{array}{l}\text { Diabetic patients who } \\
\text { didn't receive oral zinc } \\
\qquad(\mathrm{n}=25)\end{array}$ & $\begin{array}{l}\text { Controls } \\
(n=25)\end{array}$ & F & $p$-value & I\&II & I\&III & II\&III \\
\hline \multicolumn{9}{|l|}{ Before zinc: } \\
\hline Range & $0.4-1.1$ & $0.3-0.8$ & $0.3-0.5$ & 18.446 & $<0.001 *$ & 0.071 & $<0.001 *$ & $0.001^{*}$ \\
\hline Mean \pm SD & $0.620 \pm 0.163$ & $0.532 \pm 0.160$ & $0.384 \pm 0.075$ & & & & & \\
\hline \multicolumn{9}{|l|}{ After zinc: } \\
\hline Range & $0.3-0.6$ & $0.4-1.1$ & $0.3-0.5$ & 60.681 & $<0.001 *$ & $<0.001 *$ & 0.948 & $<0.001 *$ \\
\hline Mean \pm SD & $0.372 \pm 0.094$ & $0.744 \pm 0.202$ & $0.384 \pm 0.075$ & & & & & \\
\hline \multicolumn{9}{|l|}{ Differences: } \\
\hline Mean \pm SD & $0.248 \pm 0.153$ & $-0.212 \pm 0.117$ & & & & & & \\
\hline \multicolumn{9}{|l|}{ Paired test: } \\
\hline$p$-value & $<0.001 *$ & $<0.001 *$ & & & & & & \\
\hline
\end{tabular}

MPI: Myocardial performance index.

Table (7) demonstrated that the MPI was significantly higher in both studied groups than the controls before receiving oral zinc supplementation. Also MPI was significantly lower in patient who received zinc (after 6 months) than those who didn't receive zinc.
The same group who received zinc for 6 months showed no significant difference with the controls. While MPI was significantly lower in patients who didn't receive zinc supplementation than the controls after 6 months of follow-up.

Table (8): Comparison between diabetic children and control as regard LSS (Longitudinal Systolic Strain) measured by 2D STE.

\begin{tabular}{|c|c|c|c|c|c|c|c|c|}
\hline \multirow[b]{2}{*}{ 2DS } & \multicolumn{3}{|c|}{ Groups } & \multicolumn{2}{|c|}{ ANOVA } & \multicolumn{3}{|c|}{ TUKEY'S Test } \\
\hline & $\begin{array}{l}\text { Diabetic patients who } \\
\text { received oral } \\
\text { zinc }(n=25)\end{array}$ & $\begin{array}{l}\text { Diabetic patients who } \\
\text { didn't receive oral } \\
\text { zinc }(\mathrm{n}=25)\end{array}$ & $\begin{array}{l}\text { Controls } \\
(\mathrm{n}=25)\end{array}$ & $\mathrm{F}$ & $p$-value & I\&II & I\&III & II\&III \\
\hline Basal: & & & & & & & & \\
\hline $\begin{array}{l}\text { Range } \\
\text { Mean } \pm \text { SD }\end{array}$ & $\begin{array}{l}-25--13 \\
-18.360 \pm 2.644\end{array}$ & $\begin{array}{l}-27--13 \\
-19.480 \pm 3.549\end{array}$ & $\begin{array}{l}-28--19 \\
-22.800 \pm 2.500\end{array}$ & 15.479 & $<0.001 *$ & 0.373 & $<0.001 *$ & $<0.001 *$ \\
\hline $\begin{array}{l}\text { After } 6 \text { month: } \\
\text { Range } \\
\quad \text { Mean } \pm \text { SD }\end{array}$ & $\begin{array}{l}-26--16 \\
-20.920 \pm 2.871\end{array}$ & $\begin{array}{l}-24--12 \\
-16.600 \pm 3.452\end{array}$ & $\begin{array}{l}-28--19 \\
-22.800 \pm 2.500\end{array}$ & 28.700 & $<0.001 *$ & $<0.001 *$ & 0.071 & $<0.001$ * \\
\hline $\begin{array}{l}\text { Differences: } \\
\quad \text { Mean } \pm \mathrm{SD}\end{array}$ & $2.560 \pm 2.501$ & $-2.880 \pm 1.878$ & & & & & & \\
\hline $\begin{array}{l}\text { Paired test: } \\
p \text {-value }\end{array}$ & $<0.001 *$ & $<0.001 *$ & & & & & & \\
\hline
\end{tabular}

2DS: 2 dimensional strain.

Table (8) demonstrated that 2DS was significantly lower in both studied groups than the controls before receiving oral zinc supplementation Also 2DS was significantly higher in patient who received zinc (after 6 months) than those who didn't receive zinc. The same group who received zinc for 6 months showed no significant difference with the controls. While 2DS was significantly lower in patients who didn't receive zinc supplementation than the controls after 6 months of follow-up.

\section{Discussion}

The present study was done to evaluate the role of zinc as antioxidant and anti-inflammatory on the diabetic children. Also to evaluate the preventive effect of $\mathrm{Zn}$ supplementation on diabetes-induced injury to the diabetic heart.

In the present study, the serum level of IL-6 was significantly higher in both studied groups 
than the controls before receiving oral zinc supplementation.

Mirza et al., [6] determined the association between diabetes and inflammation in clinically diagnosed diabetes patients and showed that that diabetes as whole was strongly associated with elevated levels of IL-6.

Also Navarro-González et al., [7] suggested that inflammatory parameters, including inflammatory cytokines, are strong predictors of the development of diabetes. The main cytokines involved in the pathogenesis of diabetes are IL-1, TNF- a, and IL6. In addition this study in recent years have shown that inflammation, and more specifically inflammatory cytokines, are determinant in the development of microvascular diabetic complications.

This was in concordance with Devaraj et al., [8] who evaluated systemic and cellular biomarkers of inflammation in type 1 diabetic patients with microvascular complications (T1DM-MV patients) and type 1 diabetic patients without microvascular complications (T1DM patients) compared with matched controls and revealed that the level of IL6 was significantly higher in type 1 diabetic subjects with versus without microvascular complications [8].

In our study we evaluated the effect of zinc on inflammatory cytokines in the diabetic children and so assessment of level of IL6 was done after 6 months in the both diabetic groups and in the controls.

We found that serum level of IL-6 was significantly lower in patient who received zinc (after 6 months) than those who didn't receive zinc. The same group who received zinc for 6 months showed no significant difference with the controls. While IL-6 was significantly higher in patients who didn't receive zinc supplementation than the controls after 6 months of follow-up.

In our study, we found that oral zinc supplementation for 6 months lowers level of interleukin 6 as showed in results in comparison to patients who didn't receive zinc and controls.

This was in agreement with Bao et al., [9] who studied the effect of zinc on elderly subjects who received oral zinc supplementation and showed that zinc supplementation markedly decrease the level of IL6.

A study on 10 Brazilians patients with T2DM was done to evaluate the effect of diet rich in zinc on T2DM patients. Lais et al., [10] reported that level of plasma IL6 tend to decrease after zinc supplementation but not to a significant level. This may be due to short duration of study which was for 1 week and also was done for patients with T2DM.

On the contrary, Foster et al., [11] found that there is no significant effect of zinc supplementation were observed on inflammatory markers concentration including IL6 in 48 postmenopausal women with type $2 \mathrm{DM}$ but the study was done on old age group with different dose of oral zinc supplementation.

Cardiovascular disease is the major complication of diabetes, accounting for $50 \%$ of all diabetes mortality [12].

This is not only due to coronary artery disease and associated hypertension, but also to the direct adverse effect of diabetes on the heart, irrespective of other cardiovascular risk factors, called diabetic cardiomyopathy [13]. Our study was done to evaluate the asymptomatic cardiac insult in the diabetic patients and to study the role of zinc as a cardioprotective element.

There was no statistically significant difference as regard to EF (ejection fraction) that was evaluated by Tissue Doppler between both groups and the controls. This was in agreement with Nakai et al. [14]. Also there was no statistically significant difference as regard S (Mitral Annulus Systolic Velocity) between both groups more and the controls in the start of the study and 6 months latter.

After assessment of E/A ratio by Tissue Doppler, we found that the E/A ratio was significantly lower in both studied groups than the controls before receiving oral zinc supplementation. This showed that there was impairment in E/A ratio in the diabetic groups than the controls which showed subclinical impaired diastolic function in the diabetic patients.

This was in agreement with Pattoneri et al. [15] who studied group of diabetic patients with normal blood pressure without coronary artery disease to evaluate and predict early subclinical diastolic and systolic dysfunction. All subjects underwent twodimensional and Doppler echocardiogram. The diastolic function, evaluated as the mean of E/A ratios in the diabetic patients was significantly different when were compared to normal subjects, although within the normal range [15].

Also this was in agreement with Ernande et al. [16] who studied group of T2DM patients with 
controlled blood pressure and with no overt heart disease. The study showed that diastolic parameters were altered in patients compared with controls with lower E/A ratios.

Also the present study showed that the E/A ratio was significantly higher in patient who received zinc (after 6 months) than those who didn't receive zinc. The same group who received zinc for 6 months shows no significant difference with the control. While E/A ratio was significantly lower in patients who didn't receive zinc supplementation than the controls after 6 months of follow-up. We found that there was marked improvement according to E/A ratio in the diabetic patients after oral zinc supplementation with improvement in the diastolic function.

After assessment of MPI (Myocardial Performance Index) by tissue Doppler, we found that the MPI was significantly higher in both studied groups than the controls before receiving oral zinc supplementation. This showed that MPI is higher in the diabetic groups than the control which showed subclinical impaired diastolic and systolic functions in the diabetic patients.

This was in concordance with Pattoneri et al. [15] who found that myocardial performance index (MPI) was significantly higher in diabetic patients independently of the hypertension occurrence, compared to the controls.

Thus, an early involvement of left ventricular performance was shown by myocardial performance index in patients with type 2 diabetes. These abnormalities can provide a feasible approach to detect a pre-clinical diabetic cardiomyopathy and could be useful for an indirect assessment of the metabolic control.

The present study showed that MPI (myocardial performance index) was significantly lower in patient who received zinc (after 6 months) more than those who didn't receive zinc. The same group who received zinc for 6 months showed no significant difference with the controls. While MPI was significantly lower in patients who didn't receive zinc supplementation more than the controls after 6 months of follow-up.

The study showed that there was marked improvement according to MPI in the diabetic patients after oral zinc supplementation with improvement in the systolic and diastolic function.

According to the parameters taken by Speckle tracking imaging as 2DS (2 dimensional strain):
2DS was significantly lower in both studied groups than the controls before receiving oral zinc supplementation. This showed impairment of the longitudinal function as assessed by $2 \mathrm{D}$-global longitudinal strain in the diabetic groups than the control. This may be explained as the subendocardial myocardial fibers which are more vulnerable to early manifestation of ischemia and left ventricular (LV) systolic dysfunction stand longitudinally [17].

This is confirmed by Ringle et al. [18] performed echo (Conventional, 2D and 3D- speckle tracking echocardiography) on Sixty-six asymptomatic type 1 diabetic patients with no cardiovascular risk factors were compared to 26 matched healthy controls to assess the long-term evolution of left ventricular (LV) function.

The study done by Ringle et al. [18] showed that diabetic patients had impaired longitudinal function, as assessed by 2D-global longitudinal strain (GLS). At follow-up, diabetic patients had worsened longitudinal function compared to baseline. Global circumferential (GCS) and radial (GRS) strains were unchanged at baseline and during follow-up [18]

Nakai et al. [14] also have similar study on a group of diabetic patient. This study shows that Longitudinal Strain was significantly reduced in diabetic patients compared with age-matched control subjects.

Ernande et al. [16] showed that 2D longitudinal and radial functions of each LV segment are impaired in diabetic participants [16], also $\mathrm{Ng}$ et al., [19] found that only 2D longitudinal deformation was reduced in diabetic patients, whereas circumferential and radial strain were preserved.

The present study showed that 2DS was significantly higher in patient who received zinc (after 6 months) than those who didn't receive zinc. The same group who received zinc for 6 months shows no significant difference with the controls. While 2DS was significantly lower in patients who didn't receive zinc supplementation than the controls after 6 months of follow-up.

The study showed that there was marked improvement of the longitudinal function assessed by 2DS in the diabetic patients after oral zinc supplementation.

In our study there was a significant subclinical impairment in the systolic and diastolic function in the diabetic groups compared to the controls 
demonstrated by early affection of MPI and decrease of E/A ratio detected by tissue Doppler and impairment of the longitudinal function as assessed by $2 \mathrm{D}$-global longitudinal strain.

In this study we aimed to evaluate the role of zinc as anti-inflammatory and cardio-protective and found that there was significant improvement in the diabetic groups who received oral zinc supplementation in relation to the other diabetic group who didn't receive zinc and the controls. This was demonstrated $b$ the significant decrease of the level of IL6, also marked improvement of the echo parameters as MPI and E/A ratio assessed by tissue Doppler and also marked improvement of the the longitudinal function as assessed by $2 \mathrm{D}$ global longitudinal strain.

Lu et al. [20] had a similar result, using a rat model of diabetic cardiomyopathy experimentally induced by high fat diet and STZ administration, this study demonstrated that $\mathrm{Zn}$ supplementation was sufficient to protect against diabetic cardiomyopathy as Zn supplementation had limited effects against diastolic dysfunction in rats with diabeties also by reducing oxidative stress in cardiac tissue.

Wang et al. [21] had a study showed that zinc supplementation can protect against diabetic cardiomyopathy through cardiac MT induction in experimental diabetic rat models.

Several studies have shown that $\mathrm{Zn}$ supplementation has potential antioxidant as well as cardioprotective effects and promotes healthy lipid profile $[22,23]$

\section{Conclusion:}

There is evidence of increase level of serum interleukin 6 in patients with type $1 \mathrm{DM}$. There is evidence of subclinical systolic and diastolic dysfunction in asymptomatic diabetic patients assessed by two-dimensional speckle tracking echocardiography and Tissue Doppler. Oral Zinc supplementation has a significant beneficial effect in patients with type $1 \mathrm{DM}$ due to the anti-inflammatory and cardio-protective effect of the Zinc.

\section{Acknowledgments:}

This research was carried out without funding.

\section{Conflicts of interest:}

No conflicts of interest declared.

\section{Authors' contributions:}

All authors had equal role in design, work, statistical analysis and manuscript writing. All authors have approved the final article work.

\section{References}

1- JAIN S.K., RAINS J., CROAD J., et al.: Curcumin supplementation lowers TNF- $\alpha$, IL-6, IL-8, and MCP-1 secretion in high glucose-treated cultured monocytes and blood levels of TNF- $\alpha$, IL-6, MCP-1, glucose, and glycosylated hemoglobin in diabetic rats. Antioxidants \& redox signaling. Feb., 1; 11 (2): 241-9, 2009.

2- ZHENG C, WU F. and CAI L.: Transforaminal percutaneous endoscopic discectomy in the treatment of far lateral lumbar disc herniations in children. Int. Orthop., 40 (6): 1099-1102, 2016

3- EL-ZINY M., SALEM N., EL-HAWARY A., et al.: Epidemiology of Childhood Type 1 Diabetes Mellitus in Nile Delta, Northern Egypt-a retrospective study. Journal of clinical research in pediatric endocrinology, Mar., 6 (1): 9,2014

4- PITTAS A.G., WESTCOTT G.P. and BALK E.M.: Efficacy, safety, and patient acceptability of Technosphere inhaled insulin for people with diabetes: A systematic review and meta-analysis. The lancet Diabetes \& endocrinology. Nov., 1; 3 (11): 886-94, 2015.

5- RAHMAN K.: Studies on free radicals, antioxidants, and cofactors. Clin. Interv. Aging., 2: 219-236, 2007.

6- MIRZA S., HOSSAIN M., MATHEWS C., et al.: Type 2-diabetes is associated with elevated levels of TNFalpha, IL-6 and adiponectin and low levels of leptin in a population of Mexican Americans: A cross-sectional study. Cytokine. Jan., 1; 57 (1): 136-42, 2012.

7- NAVARRO-GONZÁLEZ J.F. and MORA-FERNÁNDEZ C.: The role of inflammatory cytokines in diabetic nephropathy. Journal of the American Society of Nephrology. Mar., 1; 19 (3): 433-42, 2008

8- DEVARAJ S., CHEUNG A.T., JIALAL I., et al.: Evidence of increased inflammation and microcirculatory abnormalities in patients with type 1 diabetes and their role in microvascular complications. Diabetes. Nov., 1; 56 (11): 2790-6, 2007.

9- BAO B., PRASAD A.S., BECK F.W., et al.: Zinc decreases C-reactive protein, lipid peroxidation, and inflammatory cytokines in elderly subjects: A potential implication of zinc as an atheroprotective agent-. The American journal of clinical nutrition. Apr., 28; 91 (6): 1634-41, 2010.

10- LAIS L.L., de LIMA VALE S.H., XAVIER C.A., et al.: Effect of A One-Week Balanced Diet on Expression of Genes Related to Zinc Metabolism and Inflammation in Type 2 Diabetic Patients. Clinical nutrition research. Jan., 1; 5 (1): 26-32, 2016.

11-FOSTER M., PETOCZ P. and SAMMAN S.: Inflammation markers predict zinc transporter gene expression in women with type 2 diabetes mellitus. The Journal of nutritional biochemistry. Sep., 1; 24 (9): 1655-61, 2013.

12- FEDERATION I.D. and ATLAS I.D.: International Diabetes Federation. IDF diabetes atlas, 6 th edn Brussels, Belgium: International Diabetes Federation, 2013.

13- ERNANDE L. and DERUMEAUX G.: Diabetic cardiomyopathy: Myth or reality? Archives of cardiovascular diseases. Apr., 1; 105 (4): 218-25, 2012.

14- NAKAI H., TAKEUCHI M., NISHIKAGE T., et al.: Subclinical left ventricular dysfunction in asymptomatic 
diabetic patients assessed by two-dimensional speckle tracking echocardiography: Correlation with diabetic duration. European Journal of Echocardiography. Jul., 20; 10 (8): 926-32, 2009.

15- PATTONERI P., SOZZI F.B., CATELLANI E., et al.: Myocardial involvement during the early course of type 2 diabetes mellitus: usefulness of Myocardial Performance Index. Cardiovascular ultrasound. Jun., 6 (1): 27, 2008.

16- ERNANDE L., BERGEROT C., RIETZSCHEL E.R., et al.: Diastolic dysfunction in patients with type 2 diabetes mellitus: Is it really the first marker of diabetic cardiomyopathy?. Journal of the American Society of Echocardiography. Nov., 1; 24 (11): 1268-75, 2011.

17-ZOROUFIAN A., RAZMI T., TAGHAVI-SHAVAZI M. et al.: Evaluation of subclinical left ventricular dysfunction in diabetic patients: Longitudinal strain velocities and left ventricular dyssynchrony by two-dimensional speckle tracking echocardiography study. Echocardiography. Apr., 31 (4): 456-63, 2014.

18- RINGLE A., DORNHORST A., REHMAN M.B., et al.: Evolution of subclinical myocardial dysfunction detected by two-dimensional and three-dimensional speckle tracking in asymptomatic type 1 diabetic patients: A long term follow-up study. Echo research and practice. Dec., $1 ; 4$ (4): 73-81, 2017.

19- NG A., DELGADO V., BERTINI M., et al.: Findings from left ventricular strain and strain rate imaging in asymptomatic patients with type 2 diabetes mellitus. Am. J. Cardiol., 104: 1398-401, 2009.

20- LU Y., LIU Y., LI H., et al.: Effect and mechanisms of zinc supplementation in protecting against diabetic cardiomyopathy in a rat model of type 2 diabetes. Bosnian Journal of Basic Medical Sciences. Feb., 15 (1): 14, 2015.

21- WANG J., SONG Y., ELSHERIF L., et al.: Cardiac metallothionein induction plays the major role in the prevention of diabetic cardiomyopathy by zinc supplementation. Circulation. Jan., 31; 113 (4): 544-54, 2006.

22- FOSTER M. and SAMMAN S.: Zinc and redox signaling: perturbations associated with cardio vascular disease and diabetes mellitus. Antioxid Redox Signal, 13: 1549-1573, 2010.

23- JAYAWARDENA R., RANASINGHE P., GALAPPATTHY P., et al.: Effects of zinc supplementation on diabetes mellitus: A systematic review and meta-analysis. Diabetol. Metab. Syndr, 4: 13, 2012. 


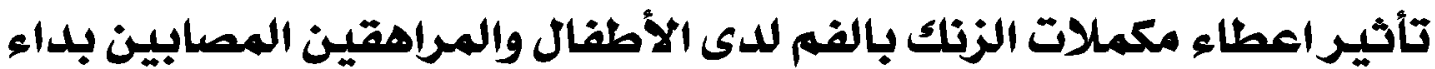

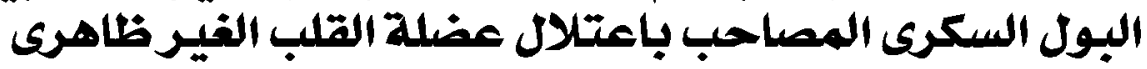

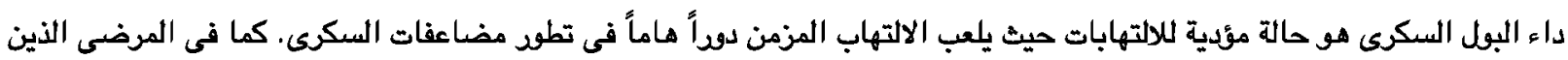

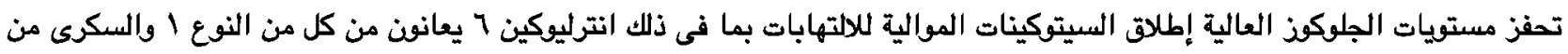

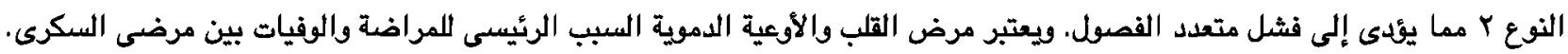

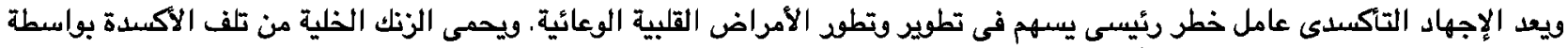
الجذود الحرة. وكذلك يعمل الزتك أيضاً بمثابة مضاد للالالتهابات.

الهدف من الدراسة: دراسة تأثير مكملات الزنك بالفم على مستمى الانترليوكين 7 فى مرضى البول السكرى وكذلك تأثيرها على وظائف عضلة القلب لمرضى البول السكرى.

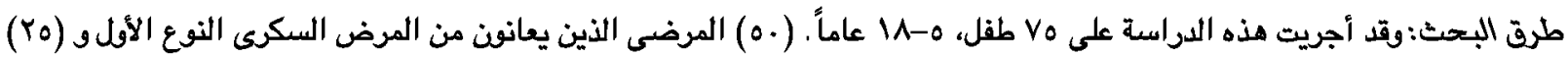

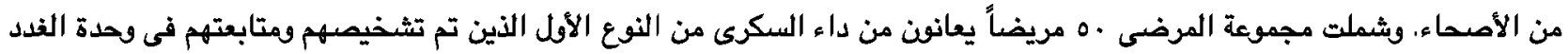

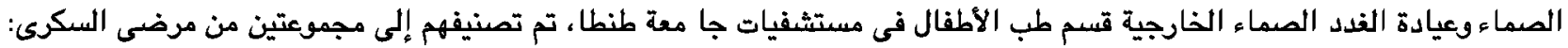
المجموعة الأولى أ:

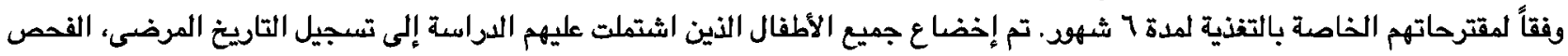

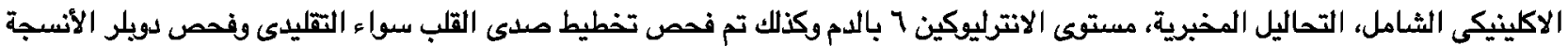
وكذلك فحص تتبع الرقعة لجميع الحالات التايل

النتائج: تبين من البحث أن الأطفال المصابين بمرض البول السكرى لديهم ارتفاع فى مستوى السيتوكين 7 وكذلك أن هؤلاء الأطفال

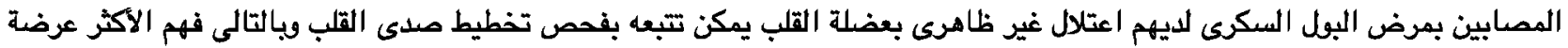

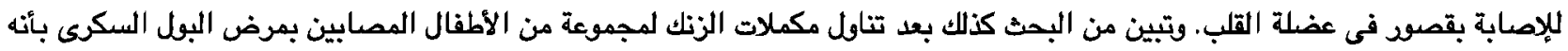

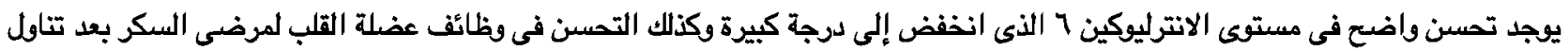
مكملات الزنك.

الاستتاج: مكملات الزتك بالفم تساعد بشكل واضِح على التقليل من مستوى الانترليوكين 7 حيث أنها من العوامل الهامة المضادة للالاتهاب وكتلك تساعد على تحسين وظائف عضلة القلب فى مرضى البول السكرى المصاحبين باعتلال غير ظاهرى في عضلة القيلة القلب.

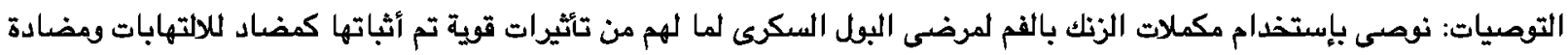

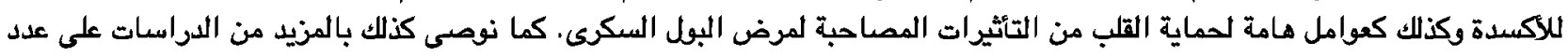

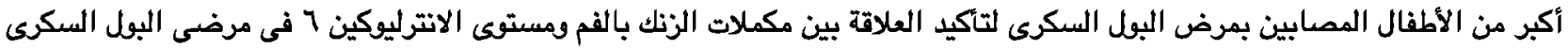

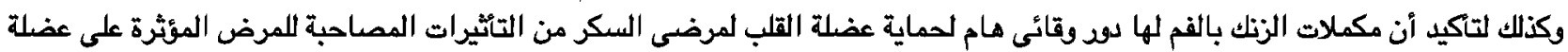

